\title{
Acid-Base Balance in Uremic Rats with Vascular Calcification
}

\author{
Alan Peralta-Ramírez ${ }^{a, c}$ Ana Isabel Raya ${ }^{a}$ Carmen Pineda ${ }^{a}$ \\ Mariano Rodríguez ${ }^{b} \quad$ Escolástico Aguilera-Tejero ${ }^{a}$ Ignacio López ${ }^{a}$ \\ a Departamento Medicina y Cirugía Animal, and bIMIBIC, Hospital Reina Sofía, Universidad \\ de Córdoba, Córdoba, Spain; ' Escuela de Medicina Veterinaria, Universidad Nacional \\ Autónoma de Nicaragua (UNAN-León), León, Nicaragua
}

Key Words

Acid-base balance $\cdot$ Chronic kidney disease $\cdot$ Rat $\cdot$ Vascular calcification

\begin{abstract}
Background/Aims: Vascular calcification (VC), a major complication in humans and animals with chronic kidney disease (CKD), is influenced by changes in acid-base balance. The purpose of this study was to describe the acid-base balance in uremic rats with VC and to correlate the parameters that define acid-base equilibrium with VC. Methods: Twenty-two rats with CKD induced by $5 / 6$ nephrectomy $(5 / 6 \mathrm{Nx})$ and 10 nonuremic control rats were studied. Results: The $5 / 6 \mathrm{Nx}$ rats showed extensive VC as evidenced by a high aortic calcium $(9.2 \pm 1.7 \mathrm{mg} / \mathrm{g}$ of tissue) and phosphorus (20.6 $\pm 4.9 \mathrm{mg} / \mathrm{g}$ of tissue) content. Uremic rats had an increased $\mathrm{pH}$ level $(7.57 \pm 0.03)$ as a consequence of both respiratory $\left(\mathrm{PaCO}_{2}=28.4 \pm 2.1 \mathrm{~mm} \mathrm{Hg}\right)$ and, to a lesser degree, metabolic (base excess $=4.1 \pm 1 \mathrm{mmol} / \mathrm{l}$ ) derangements. A high positive correlation between both anion gap (AG) and strong ion difference (SID) with aortic calcium (AG: $r=0.604, p=0.02 ;$ SID: $r=0.647, p=0.01$ ) and with aortic phosphorus (AG: $r=0.684$, $p=0.007$; SID: $r=0.785, p=0.01$ ) was detected. Conclusions: In an experimental model of uremic rats, VC showed high positive correlation with AG and SID.

(C) 2014 S. Karger AG, Basel
\end{abstract}

\section{Introduction}

Chronic kidney disease (CKD) is a major health problem [1, 2]. Arteriosclerosis and atherosclerosis are common features in patients with CKD $[3,4]$. Vascular calcification (VC) significantly contributes to the high rate of cardiovascular mortality associated with CKD [5, 
6]. In uremic patients, VC is caused in part by a deranged mineral metabolism, including hyperphosphatemia, hypercalcemia and abnormal PTH levels [7].

Changes in acid-base balance are known to influence VC. Acidosis has been reported to decrease VC [8], whereas alkalosis is thought to increase VC $[9,10]$. The information on the influence of the acid-base status on VC has been obtained from two major groups of studies: (1) experiments in which the acid-base balance has been severely modified (e.g. by inducing acidosis) $[8,10]$, and (2) epidemiological studies carried out with human patients on dialysis $[11,12]$.

Although a great deal of knowledge about VC secondary to renal failure has been obtained from experimental models of uremic rats [13-16], to our knowledge, associations between changes in the acid-base balance and VC in uremic rats not subjected to artificial $\mathrm{pH}$ changes have not been reported. The present study is aimed to describe the acid-base balance in uremic rats with VC and to correlate the parameters that define acid-base equilibrium with the vascular mineral content of these rats. We hypothesize that a strong correlation between changes in the acid-base balance and VC would be found.

\section{Methods}

\section{Animals and Surgical Procedures}

Zucker $o b / o b$ rats $(\mathrm{n}=32)$ provided by Harlan Laboratories Models (Barcelona, Spain) were housed under a 12-/12-hour light/dark cycle and given ad libitum access to a standard $\operatorname{diet}$ (calcium $=0.6 \%$, phosphorus $=0.6 \%$ ). CKD was induced in 22 rats, and 10 rats were used as controls. For this rodent model of CKD, a 5/6 nephrectomy (5/6 Nx) was used, that is, a two-step procedure that reduces the original functional renal mass by five-sixths $(5 / 6)$. In the first step, the animals were anesthetized, an 8-mm incision was made on the left mediolateral surface of the abdomen, and the left kidney was exposed. The two renal poles were tightly ligated and ablated, thus leaving $1 / 3$ of the original renal mass. After 1 week of recovery, the animal was reanesthetized, and an 8-mm incision was made on the right mediolateral surface of the abdomen. The right kidney was exposed and unencapsulated, the renal pedicle clamped and ligated, and the kidney was removed. After the second surgery, the mineral content of the diet was changed to $0.6 \%$ calcium and $0.9 \%$ phosphorus, and the rats were treated with calcitriol $80 \mathrm{ng} / \mathrm{kg}$ i.p. (Calcijex; Abbot, Madrid, Spain) every other day (three times per week) to control secondary hyperparathyroidism. Nephrectomized rats were fed with the highphosphate diet and treated with calcitriol for 15 days; then, they were sacrificed. Euthanasia was performed $24 \mathrm{~h}$ after receiving the last dose of calcitriol. All experimental protocols were reviewed and approved by the Ethics Committee for Animal Research of the University of Córdoba (Spain).

\section{Assessment of VC}

Following sacrifice, the thoracic aorta was dissected and processed to study the mineral content. Calcification was studied by measuring the aortic calcium and phosphorus content. The tissues were demineralized in 10\% formic acid, and the calcium and phosphorus content was measured in the supernatant according to a method previously described [13].

\section{Blood Chemistries}

Blood for chemistry analyses was obtained from the abdominal aorta at the time of sacrifice. Blood for the measurement of the acid-base balance was collected in heparinized syringes and immediately analyzed using a Ciba-Corning 800 series blood gas analyzer (CibaCorning, Essex, UK). Measurements of $\mathrm{pH}, \mathrm{PaCO}_{2}, \mathrm{Na}, \mathrm{K}, \mathrm{Cl}$ and ionized calcium $\left(\mathrm{Ca}^{2+}\right)$ were 
Table 1. Blood parameters of renal function and mineral metabolism, and aortic mineral content in uremic $(5 / 6 \mathrm{Nx})$ and control rats
Peralta-Ramírez et al.: Acid-Base Balance in Uremic Rats with Vascular Calcification

\begin{tabular}{lrl}
\hline & \multicolumn{1}{c}{$\begin{array}{l}5 / 6 \mathrm{Nx} \\
(\mathrm{n}=22)\end{array}$} & $\begin{array}{l}\text { Control } \\
(\mathrm{n}=10)\end{array}$ \\
\hline Plasma creatinine, mg/dl & $1.36 \pm 0.08$ & $0.44 \pm 0.02^{* *}$ \\
Plasma ionized calcium, mmol/l & $1.12 \pm 0.06$ & $1.26 \pm 0.03^{*}$ \\
Plasma phosphate, $\mathrm{mg} / \mathrm{dl}$ & $10.11 \pm 0.54$ & $6.90 \pm 0.44^{* *}$ \\
Plasma calcitriol, pg/ml & $254.1 \pm 49.1$ & $22.4 \pm 11.5^{*}$ \\
Plasma PTH, pg/ml & $120.9 \pm 19.1$ & $27.3 \pm 2.7^{*}$ \\
Aortic calcium, mg/g & $9.20 \pm 1.66$ & $0.01 \pm 0.01^{* *}$ \\
Aortic phosphorus, mg/g & $20.60 \pm 4.86$ & $0.01 \pm 0.01^{* *}$ \\
\hline
\end{tabular}

Values are means \pm SE. ${ }^{*} \mathrm{p}<0.05{ }^{* *} \mathrm{p}<0.01$ vs. $5 / 6 \mathrm{Nx}$.

made using selective electrodes. From these parameters, values of $\mathrm{HCO}_{3}$, concentration of total carbon dioxide $\left(\mathrm{CtCO}_{2}\right)$, base excess $(\mathrm{BE})$, anion gap $\left[\mathrm{AG}=(\mathrm{Na}+\mathrm{K})-\left(\mathrm{Cl}+\mathrm{HCO}_{3}\right)\right]$ and strong ion difference $(\mathrm{SID}=(\mathrm{Na}+\mathrm{K})-\mathrm{Cl})$ were calculated. Afterwards, plasma was separated by centrifugation and stored at $-20^{\circ} \mathrm{C}$ until assayed. Plasma creatinine and phosphorus were measured by spectrophotometry (BioSystems SA, Barcelona, Spain). PTH levels were quantified according to the vendor's instructions using a rat $\mathrm{PTH}_{(1-34)}$ immunoradiometric assay kit (Immunotopics, San Clemente, Calif., USA). Radioimmunoassay was used to determine $1,25(\mathrm{OH})_{2} \mathrm{D}_{3}$ in plasma samples (IDS kit, Boldon, UK).

\section{Statistics}

Values are expressed as the mean \pm standard error (SE). The difference between means was assessed by ANOVA. A correlation study was carried out using the Pearson test. $p<0.05$ was considered significant.

\section{Results}

As shown in table 1,5/6 $\mathrm{Nx}$ rats had a typical uremic blood profile, including elevated creatinine $(1.36 \pm 0.08 \mathrm{mg} / \mathrm{dl})$, low $\mathrm{Ca}^{2+}(1.12 \pm 0.06 \mathrm{mmol} / \mathrm{l})$ and high phosphate $(10.1 \pm 0.5$ $\mathrm{mg} / \mathrm{dl})$. These rats also showed extensive $\mathrm{VC}$ as evidenced by the high aortic calcium $(9.2 \pm$ $1.7 \mathrm{mg} / \mathrm{g}$ of tissue) and phosphorus (20.6 $\pm 4.9 \mathrm{mg} / \mathrm{g}$ of tissue) content. Both PTH (120.9 \pm $19.1 \mathrm{pg} / \mathrm{ml})$ and calcitriol $(254.1 \pm 49.1 \mathrm{pg} / \mathrm{ml})$ were elevated in the $5 / 6 \mathrm{Nx}$ rats. The control group had normal renal function, normal parameters of mineral metabolism and did not show extraskeletal calcification.

Table 2 depicts the acid-base balance in the study animals. The elevated blood $\mathrm{pH}$ detected in the $5 / 6 \mathrm{Nx}$ group $(7.57 \pm 0.03)$ revealed a tendency to alkalemia. The increased $\mathrm{pH}$ was a consequence of both respiratory $\left(\mathrm{PaCO}_{2}=28.4 \pm 2.1 \mathrm{~mm} \mathrm{Hg}\right)$ and, to a lesser degree, metabolic $\left(\mathrm{HCO}_{3}=25.1 \pm 1.1 \mathrm{mmol} / \mathrm{l}\right)$ derangements. This alkalotic trend was also reflected in $\mathrm{BE}$ $(4.1 \pm 1 \mathrm{mmol} / \mathrm{l})$. No major changes were found in other electrolytes. Rats from the control group showed normal acid-base parameters.

The correlation between the aortic calcium and phosphorus content and acid-base parameters is shown in table 3. A positive correlation was found between blood $\mathrm{pH}$ and both aortic calcium or phosphorus concentration. $\mathrm{PaCO}_{2}$ and $\mathrm{HCO}_{3}$ showed weak negative correlations with aortic mineralization. However, the most striking fact was the high positive correlation of both AG and SID with aortic calcium (AG: $r=0.604, p=0.02 ;$ SID: $r=0.647, p=0.01$ ) as well as with aortic phosphorus (AG: $r=0.684, p=0.007$; SID: $r=0.785, p=0.01$ ) (fig. 1). 
Table 2. Blood acid-base parameters and electrolytes in uremic $(5 / 6 \mathrm{Nx})$ and control rats (see Methods for details)
Table 3. Correlation between aortic mineral content and blood acid-base parameters in uremic $(5 / 6 \mathrm{Nx})$ rats (see Methods for details)
Peralta-Ramírez et al.: Acid-Base Balance in Uremic Rats with Vascular Calcification

\begin{tabular}{lrc}
\hline & $\begin{array}{c}5 / 6 \mathrm{Nx} \\
(\mathrm{n}=22)\end{array}$ & $\begin{array}{c}\text { Control } \\
(\mathrm{n}=10)\end{array}$ \\
\hline $\mathrm{pH}$ & $7.57 \pm 0.03$ & $7.36 \pm 0.1^{* *}$ \\
$\mathrm{paCO}_{2}, \mathrm{~mm} \mathrm{Hg}$ & $28.44 \pm 2.11$ & $44.31 \pm 2.21^{* *}$ \\
$\mathrm{HCO}_{3}{ }^{-}, \mathrm{mmol} / \mathrm{l}$ & $25.04 \pm 1.06$ & $24.52 \pm 1.32$ \\
$\mathrm{ctCO}_{2}, \mathrm{mmol} / \mathrm{l}$ & $25.95 \pm 1.11$ & $25.90 \pm 1.38$ \\
$\mathrm{BE}, \mathrm{mmol} / \mathrm{l}$ & $4.06 \pm 1.02$ & $-1.11 \pm 1.11^{* *}$ \\
$\mathrm{Na}, \mathrm{mmol} / \mathrm{l}$ & $143.08 \pm 0.60$ & $135.98 \pm 1.36^{*}$ \\
$\mathrm{~K}, \mathrm{mmol} / \mathrm{l}$ & $4.89 \pm 0.15$ & $4.09 \pm 0.16$ \\
$\mathrm{Cl}, \mathrm{mmol} / \mathrm{l}$ & $111.23 \pm 1.29$ & $106.11 \pm 1.72$ \\
$\mathrm{AG}, \mathrm{mmol} / \mathrm{l}$ & $10.42 \pm 1.48$ & $9.1 \pm 1.3$ \\
$\mathrm{SID}, \mathrm{mmol} / \mathrm{l}$ & $37.37 \pm 1.97$ & $34.01 \pm 1.83$ \\
\hline
\end{tabular}

Values are means \pm SE. ${ }^{*} \mathrm{p}<0.05,{ }^{* *} \mathrm{p}<0.01$ vs. $5 / 6 \mathrm{Nx}$.

\begin{tabular}{lrllll}
\hline & \multicolumn{2}{c}{ Aortic calcium } & & \multicolumn{2}{c}{ Aortic phosphorus } \\
\cline { 2 - 3 } & \multicolumn{1}{c}{$\mathrm{r}$} & $\mathrm{p}$ & & $\mathrm{r}$ & $\mathrm{p}$ \\
\hline $\mathrm{pH}$ & 0.491 & 0.020 & & 0.559 & 0.007 \\
$\mathrm{paCO}_{2}$ & -0.542 & 0.011 & & -0.647 & 0.002 \\
$\mathrm{HCO}_{3}{ }^{-}$ & -0.407 & 0.060 & & -0.444 & 0.039 \\
$\mathrm{ctCO}_{2}$ & -0.424 & 0.049 & & -0.464 & 0.030 \\
$\mathrm{BE}$ & -0.057 & 0.801 & & 0.048 & 0.832 \\
$\mathrm{Na}$ & 0.261 & 0.368 & & 0.475 & 0.086 \\
$\mathrm{~K}$ & -0.325 & 0.140 & & -0.461 & 0.031 \\
$\mathrm{Cl}$ & -0.085 & 0.705 & & 0.094 & 0.676 \\
\hline
\end{tabular}

\section{Discussion}

With the experimental protocol described here, $5 / 6 \mathrm{Nx}$ rats were not acidotic, as classically described in uremic animals and men $[11,12,17]$, but rather alkalotic. The reason for this alkalotic trend is unknown but may relate to the severity of extraskeletal calcification. The relationship between alkalosis and calcifications seems to be bidirectional; alkalosis promotes calcification and calcification may also increase blood $\mathrm{pH}$. The rationale behind finding an increase in blood $\mathrm{pH}$ in animals with soft tissue calcification is that in the calcification process some mineral is diverted from the bone to the extraosseous tissue [18], and in this process there is transference of bone buffer to extracellular fluid. Nevertheless, the simultaneous presence of alkalosis and calcification reinforces the concept that acidifying the extracellular fluid is a valid therapeutic intervention to prevent and treat VC [8].

The influence of the acid-base status on VC has been studied in detail. Metabolic acidosis has been shown to protect against VC [8]. A positive correlation between blood bicarbonate levels and VC has been reported in patients on hemodialysis [19]. Alkalinization seems to potentiate vascular calcium deposition [10], but a recent study has reported that alkaline $\mathrm{pH}$ stabilizes primary calcioprotein particles and inhibits their transition to secondary calcioprotein particles [20]. Our results support the association between $\mathrm{VC}$ and alkalotic trends in uremic rats. 


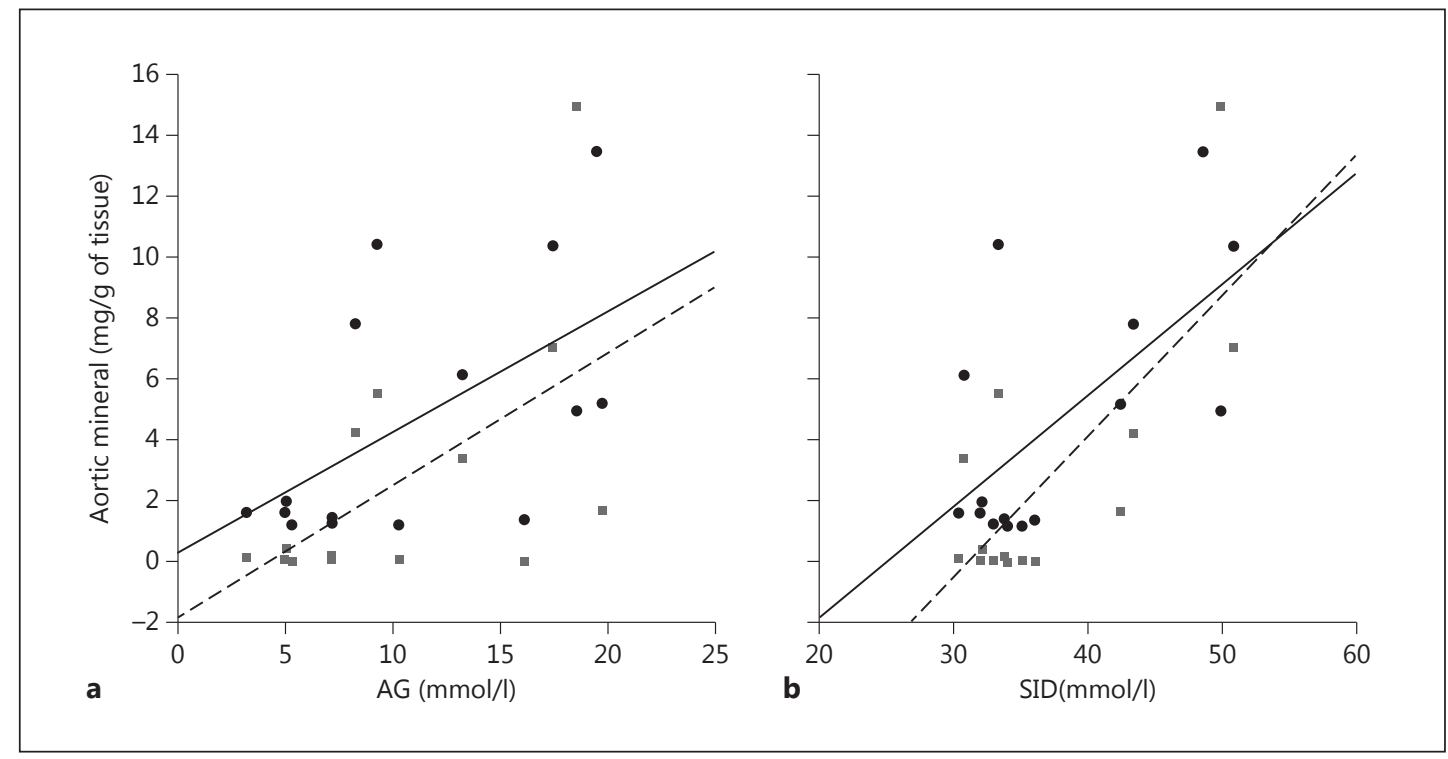

Fig. 1. a Correlation between aortic mineral content and AG. b Correlation between aortic mineral content and SID. Squares and the broken line represent aortic calcium $(r=0.604, p=0.02$ vs. AG: $r=0.647, p=0.01$ vs. SID), and circles and the continuous line represent aortic phosphorus ( $r=0.684, p=0.007$ vs. AG: $r=0.785$, $\mathrm{p}=0.001$ vs. SID).

Although the mean values of $A G$ in $5 / 6 \mathrm{Nx}$ rats were within reference ranges of the control group, individual 5/6 Nx rats had elevated AG which was associated with more severe calcifications. Increased AG has been reported to be linked with a higher mortality risk in earlyCKD patients [21]. Hyperphosphatemia, a major feature in uremic rats, contributes to the elevation of AG. On the other hand, the elevated AG level is likely to be influenced by an increase in unidentified/nonmeasured anions (e.g. uremic toxins). The positive correlation between AG and mineral deposition in the vasculature suggests that electrolyte equilibrium is important in the development of VC. This hypothesis is further supported by the high correlation found between SID and aortic mineral content. The mechanism that may link VC and electrolyte equilibrium is not clear, but the calcium-sensing receptor (CaSR) may be involved. Although its role in $\mathrm{VC}$ is not completely understood, the CaSR has been hypothesized to play a role in the development of VC [22]. The CaSR, which is expressed in the vessel wall, can sense changes in ionic strength independently of alterations in osmolality [23]. Activation of the CaSR by calcimimetics has been shown to be beneficial for preventing VC [13]. Thus, changes in the ionic balance of extracellular fluid may be influencing VC through interactions with the CaSR.

It is remarkable to note that the type of acidosis that has been reported to be beneficial for calcifications is hyperchloremic acidosis [8] in which no increase in AG is present. Thus, it would be interesting to perform further studies to determine (1) the role of unidentified anions (e.g. uremic toxins) in calcifications, and (2) the role of individual electrolytes which influence $\mathrm{AG}$ and SID ( $\mathrm{Na}, \mathrm{K}$, and $\mathrm{Cl}$ ) and ionic strength in VC.

In conclusion, in the present study using an experimental model of uremic rats, a weak correlation between blood $\mathrm{pH}$ and VC has been found, whereas VC showed a high positive correlation with AG and SID. 


\section{Acknowledgments}

This work was supported by a Spanish Government Grant from the Instituto de Salud Carlos III (PI11/00098) with co-financing from European Funds.

\section{References}

1 Levey AS, Atkins R, Coresh J, Cohen EP, Collins AJ, Eckardt KU, Nahas ME, Jaber BL, Jadoul M, Levin A, Powe NR, Rossert J, Wheeler DC, Lameire N, Eknoyan G: Chronic kidney disease as a global public health problem: approaches and initiatives - a position statement from Kidney Disease Improving Global Outcomes. Kidney Int 2007;72:247-259.

2 Couser WG, Remuzzi G, Mendis S, Tonelli M: The contribution of chronic kidney disease to the global burden of major noncommunicable diseases. Kidney Int 2011;80:1258-1270.

-3 Guérin AP, London GM, Marchais SJ, Mativier F: Arterial stiffening and vascular calcifications in end-stage renal disease. Nephrol Dial Transplant 2000;15:1014-1021.

-4 Foley RN, Collins, AJ: End-stage renal disease in the United States: an update from the United States Renal Data System. J Am Soc Nephrol 2007;18:2644-2648.

-5 Foley RN, Parfrey PS, Sarnak MJ: Epidemiology of cardiovascular disease in chronic renal disease. J Am Soc Nephrol 1998;9(suppl):S16-S23.

6 6 Block GA, Klassen PS, Lazarus JM, Ofsthun N, Lowrie EG, Chertow GM: Mineral metabolism, mortality, and morbidity in maintenance hemodialysis. J Am Soc Nephrol 2004;15:2208-2218.

7 Cozzolino M, Brancaccio D, Gallieni M, Slatopolsky E: Pathogenesis of vascular calcification in chronic kidney disease. Kidney Int 2005;68:429-436.

-8 Mendoza FJ, Lopez I, Montes de Oca A, Perez J, Rodriguez M, Aguilera-Tejero E: Metabolic acidosis inhibits soft tissue calcification in uremic rats. Kidney Int 2008;73:407-414.

\9 Alcázar Arroyo R: Electrolyte and acid-base balance disorders in advanced chronic kidney disease (in Spanish). Nefrologia 2008;28(suppl 3):87-93.

10 de Solis AJ, González-Pacheco FR, Deudero JJ, Neria F, Albalate M, Petkov V, Susanibar L, Fernandez-Sanchez R, Calabia O, Ortiz A, Caramelo C: Alkalinization potentiates vascular calcium deposition in an uremic milieu. J Nephrol 2009;22:647-653.

11 Harris DC, Yuill E, Chesher DW: Correcting acidosis in hemodialysis: effect on phosphate clearance and calcification risk. J Am Soc Nephrol 1995;6:1607-1612.

-12 Kirschbaum B: Effect of high bicarbonate hemodialysis on ionized calcium and risk of metastatic calcification. Clin Chim Acta 2004;343:231-236.

$\checkmark 13$ Lopez I, Aguilera-Tejero E, Mendoza FJ, Almaden Y, Perez J, Martin D, Rodriguez M: Calcimimetic R-568 decreases extraosseous calcifications in uremic rats treated with calcitriol. J Am Soc Nephrol 2006;17:795804.

14 O'Neill WC, Lomashvili KA, Malluche HH, Faugere MC, Riser BL: Treatment with pyrophosphate inhibits uremic vascular calcification. Kidney Int 2011;79:512-517.

15 Yamada S, Taniguchi M, Tokumoto M, Toyonaga J, Fujisaki K, Suehiro T, Noguchi H, Iida M, Tsuruya K, Kitazono $\mathrm{T}$ : The antioxidant tempol ameliorates arterial medial calcification in uremic rats: important role of oxidative stress in the pathogenesis of vascular calcification in chronic kidney disease. J Bone Miner Res 2012;27:474485.

-16 Jung S, Querfeld U, Müller D, Rudolph B, Peters H, Krämer S: Submaximal suppression of parathyroid hormone ameliorates calcitriol-induced aortic calcification and remodeling and myocardial fibrosis in uremic rats. J Hypertens 2012;30:2182-2191.

17 Wesson DE, Simoni J: Acid retention during kidney failure induces endothelin and aldosterone production which lead to progressive GFR decline, a situation ameliorated by alkali diet. Kidney Int 2010;78:1128-1135.

18 Hak AE, Pols HA, van Hemert AM, Hofman A, Witteman JC: Progression of aortic calcification is associated with metacarpal bone loss during menopause: a population-based longitudinal study. Arterioscler Thromb Vasc Biol 2000;20:1926-1931.

19 Oka M, Ohtake T, Mochida Y, Ishioka K, Maesato K, Moriya H, Hidaka S, Kobayashi S: Correlation of coronary artery calcification with pre-hemodialysis bicarbonate levels in patients on hemodialysis. Ther Apher Dial 2012;16:267-271.

20 Pasch A, Farese S, Gräber S, Wald J, Richtering W, Floege J, Jahnen-Dechent W: Nanoparticle-based test measures overall propensity for calcification in serum. J Am Soc Nephrol 2012;23:1744-1752.

-21 Abramowitz MK, Thomas H, Hostetter TH, Melamed ML: The serum anion gap is altered in early kidney disease and associates with mortality. Kidney Int 2012;82:701-709.

22 Molostvov G, Bland R, Zehnder D: Expression and role of the calcium-sensing receptor in the blood vessel wall. Curr Pharm Biotechnol 2009;10:282-288.

23 Quinn SJ, Kifor O, Trivedi S, Diaz R, Vassilev P, Brown E: Sodium and ionic strength sensing by the calcium receptor. J Biol Chem 1998;273:19579-19586. 